\title{
Mars Sedimentary Geology: Key Concepts and Outstanding Questions
}

\author{
John Grotzinger, ${ }^{1}$ David Beaty, ${ }^{2}$ Gilles Dromart, ${ }^{3}$ Sanjeev Gupta, ${ }^{4}$ Mitch Harris, ${ }^{5}$ Joel Hurowitz, ${ }^{6}$ \\ Gary Kocurek, ${ }^{7}$ Scott McLennan, ${ }^{8}$ Ralph Milliken, ${ }^{9}$ Gian Gabrielle Ori, ${ }^{10}$ and Dawn Sumner ${ }^{11}$
}

\section{Introduction}

$\mathbf{P}$ ROCESSES THAT OPERATE at planetary surfaces have the potential to record a history of planetary evolution in the form of sedimentary rocks. This is important because our experience on Earth shows that sediments and sedimentary rocks are the dominant archive of high-resolution proxies of present and past tectonic, climatic, and biological processes. Our understanding of the evolution of Earth's very ancient climate and paleobiological records derives from detailed examination of the mineralogical, textural, and geochemical signatures preserved in the sedimentary rock record.

Sedimentary rocks were first recognized on Mars less than a decade ago (Malin and Edgett, 2000). Recent interpretations of data collected by the Mars Express and Mars Reconnaissance Orbiter spacecraft have confirmed the surprising abundance of these sedimentary rocks, the past role of water on the martian surface, and the similarity-in some cases - to sedimentary rocks formed on Earth. Thick sulfaterich deposits invite comparison to terrestrial evaporites (Grotzinger et al., 2005). In other cases, clay-rich strata are interpreted as the terminal deposits of source-to-sink systems with well-developed fluvial networks in the upper reaches of watersheds that date back to a much wetter period in Mars' earliest history (Ehlmann et al., 2008; Metz et al., 2009). However, these Earth-like depositional systems contrast with other deposits that may be unique in the Solar System: for example, vast terrains as large as Earth's continents covered by thick veneers of strata that may derive entirely from settling out of wind-transported dust (Bridges et al., 2010). Whatever their origin, it is now clear that the sedimentary rocks of Mars represent a new frontier for research.

Mars science is in its golden era of exploration-the past decade of orbiter and landed missions has produced an ex- traordinary amount of new data relevant to the analysis of sediments and sedimentary rocks, and robust international programs exist for future missions. To help stimulate discussion of these data, the First International Conference on Mars Sedimentology and Stratigraphy was convened in El Paso, Texas, in April 2010. The contents of this white paper represent the most significant findings of the conference, with additional information provided by the coauthors, and focus on seven key questions for future investigation by the sedimentary geology community.

\section{How Can We Use the Stratigraphic Record of Mars to Extract Information on its Planetary Evolution?}

Just as Earth's sedimentary rock record has been used as a proxy for understanding the evolution of our home planet, so too should Mars' sedimentary strata provide such a record. For example, it has been widely recognized through a variety of proxies in the terrestrial sedimentary record, including the presence or absence of detrital sulfide minerals (Rasmussen and Buick, 1999), the redox behavior of Fe in paleosols (Holland and Rye, 1997), and the record of mass independent fractionation of sulfur isotopes (Farquhar et al., 2000), that Earth's atmosphere underwent a significant change in redox state associated with the rise of atmospheric $\mathrm{O}_{2}$ at around the Archean-Proterozoic boundary. Similarly, the record of continent growth and evolution is well preserved in the rare earth element patterns and $\mathrm{Nd}$-isotopic compositions of shales and mudstones that cross temporal boundaries from the Archean to Proterozoic to Phanerozoic (Taylor and McLennan, 1985). In much the same way, we may discern the nature and extent of changes in the martian environment during its evolution by examination of the mineralogical, geochemical, and isotopic composition of sedimentary rocks.

\footnotetext{
${ }^{1}$ Division of Geological and Planetary Sciences, California Institute of Technology, Pasadena, California, USA.

${ }^{2}$ Mars Program Office, Jet Propulsion Laboratory, California Institute of Technology, Pasadena, California, USA.

${ }^{3}$ Laboratoire des Sciences de la Terre, Ecole normale supérieure, Lyon, France.

${ }^{4}$ Department of Earth Science and Engineering, Imperial College, London, UK.

${ }^{5}$ Chevron Energy Technology Company, San Ramon, California, USA.

${ }^{6}$ Jet Propulsion Laboratory, California Institute of Technology, Pasadena, California, USA

${ }^{7}$ Jackson School of Earth Sciences, University of Texas, Austin, Texas, USA

${ }^{8}$ Department of Geosciences, SUNY Stony Brook, Stony Brook, New York, USA.

${ }^{9}$ Department of Civil Engineering and Geosciences, University of Notre Dame, Notre Dame, Indiana, USA.

${ }^{10}$ IRSPS, University G. d'Annunzio, Pescara, Italy.

${ }^{11}$ Department of Geology, University of California, Davis, California, USA.
} 


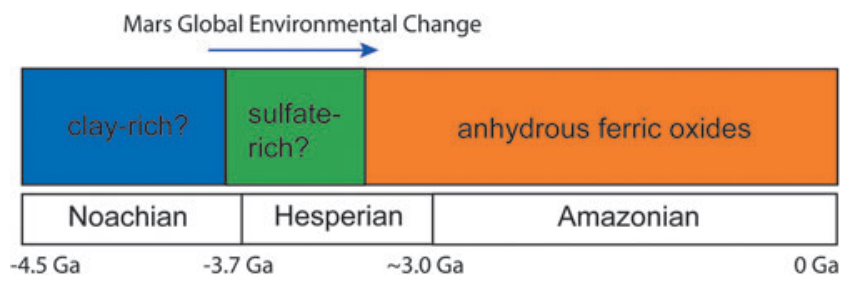

FIG. 1. One current scenario for the environmental evolution of Mars' surface environments through time (after Bibring et al., 2006). In some sites, such as Gale Crater, the stratigraphic record of hydrated minerals supports this model (Milliken et al., 2010); however, in other locations, such as Mawrth Vallis, it appears that sulfate minerals may stratigraphically underlie the clay-bearing strata (Wray et al., 2010).

As shown in Fig. 1, global mineralogical mapping from orbit indicates an evolution in weathering from a Noachian ( 4.5 to $\sim 3.7 \mathrm{Ga}$ ) era marked by neutral $\mathrm{pH}$ aqueous alteration that generated clay minerals, to a Hesperian $(\sim 3.7$ to $\sim 3.2 \mathrm{Ga}$ ) era marked by sulfate generation in an acidic environment, to an Amazonian ( $\sim 3.2$ to $0.0 \mathrm{Ga})$ era dominated by formation of anhydrous ferric oxides in a slow superficial weathering regime without liquid water (Bibring et al., 2006; McLennan and Grotzinger, 2008; Murchie et al., 2009; Milliken and Bish, 2010). The question as to whether there was a regional or global change from water-rich, circum-neutral $\mathrm{pH}$ conditions to water-poor and acidic conditions over the course of martian geological history might be answered by observing the transitions in chemistry and mineral assemblages of rocks of various ages whose stratigraphic relationships can be clearly understood. Accordingly, the relative distributions of sulfate-dominated and clay-dominated sedimentary rocks, both in space and time, are critical outstanding questions (e.g., Milliken et al., 2009).

At first pass, the succession of sedimentary rocks at key reference sections (e.g., Gale Crater; Milliken et al., 2010) appears to support the idea that sulfate-rich strata succeeded clay-rich strata. In detail, there is evidence that this transition may also be gradational as the two mineralogically defined facies are interbedded (see Fig. 2). However, there are some places where the stratigraphic order of minerals is reversed (e.g., Wray et al., 2010). It is clear that more work is required to establish the global nature and timing of mineral deposition. As on Earth, by establishing and attempting to correlate such reference sections across Mars, the history of local, regional, and global processes would likely begin to resolve itself.

Formation of clay minerals, such as smectite, from a basaltic precursor should produce an excess of cations that must reside in complementary salts such as carbonates, sulfates, chlorides, or hydroxides; these complementary salts are often missing in orbital observations of ancient claybearing strata (Milliken et al., 2009). Accordingly, the relative roles of the carbon and sulfur cycles during the first several hundred million years of Mars' history, during which clay minerals are thought to have been most readily formed, remains another open question. The examination of sedimentary assemblages (at the microscopic to outcrop scales), which preserve coeval chemical and clastic sedimentary components, would likely provide insight into this issue.

\section{What Is the Composition, Both Mineralogical and Chemical, of Modern and Ancient Martian Sediments? What Were the Global Geochemical Cycles for S and $C$, and What Role Did Sedimentary Processes Play in This Cycle?}

Evaluating the mineralogy and chemistry of martian sedimentary deposits first requires an understanding of the composition and evolution of crustal sources that weather and erode to supply sediment. The martian crust is basaltic and thus differs fundamentally from the granodioritic upper continental crust that is the provenance of most terrestrial sediment (e.g., McSween et al., 2009; Taylor and McLennan, 2009; see Fig. 3). This in turn leads to igneous mineralogy dominated by olivine, pyroxene, plagioclase, and Fe-Ti oxides (McLennan and Grotzinger, 2008; Taylor et al., 2008). In surficial environments dominated by a sulfur cycle (see below), acidic weathering of such material is heavily influenced by dissolution rather than just mineral alteration, which is prevalent in the carbon cycle-dominated weathering of quartz, plagioclase, potassium feldspar, and mica in terrestrial upper crust. A second fundamental difference between Mars and Earth is the age distribution of exposed crust. Although volcanism continues to the very recent past, most martian crust is of great antiquity with $\sim 70-90 \%$ likely to have been in place by $\sim 4 \mathrm{Ga}$ (e.g., Taylor and McLennan, 2009). How does this distinctive pattern of crustal composition and evolution influence the age distribution and recycling history of the sedimentary mass and the thermal history of sedimentary basins?

Orbital and rover-based remote sensing observations, supplemented by laboratory experiments, have identified a diverse sedimentary mineralogy, with some evidence for evolving mineralogical eras as discussed above. An important result is the apparent abundance of chemical constituents to form chemical sedimentary rocks, including a variety of magnesium sulfate, iron(III) sulfate, calcium sulfate of likely evaporative and diagenetic origins; chlorides; amorphous silica; iron oxides of varying crystallinity; and lesser occurrences of magnesium carbonate and calcium carbonate. The siliciclastic record appears dominated by basalt fragments and minerals, but in ancient Noachian terrains a variety of clay minerals have been detected, primarily $\mathrm{Fe} / \mathrm{Mg}$ varieties but locally including more aluminous compositions. The mineralogy of late and post-Noachian chemical constituents suggests a weathering regime dominated by the sulfur cycle, in which basalts were altered and sediments evolved under low fluid/rock ratios and low pH conditions (e.g., Hurowitz and McLennan, 2007; McLennan and Grotzinger, 2008; Tosca and Knoll, 2009). Such conditions may be spatially and temporally separated from the modern carbonateand perchlorate-forming environments observed at martian high latitudes by the Phoenix lander (Boynton et al., 2009; Hecht et al., 2009). The presence of clays in ancient layered terrains also suggests more modest $\mathrm{pH}$ conditions at certain times or locations. Indeed, if more clement conditions were present on Mars $>3.5 \mathrm{Ga}$, then perhaps the carbon cycle played a more prominent role. If so, then one might expect rocks indicative of that time period to contain carbonates, but to date only a few isolated occurrences of carbonates have been detected on Mars (e.g., Ehlmann et al., 2008; Michalski and Niles, 2010; Morris et al., 2010). 


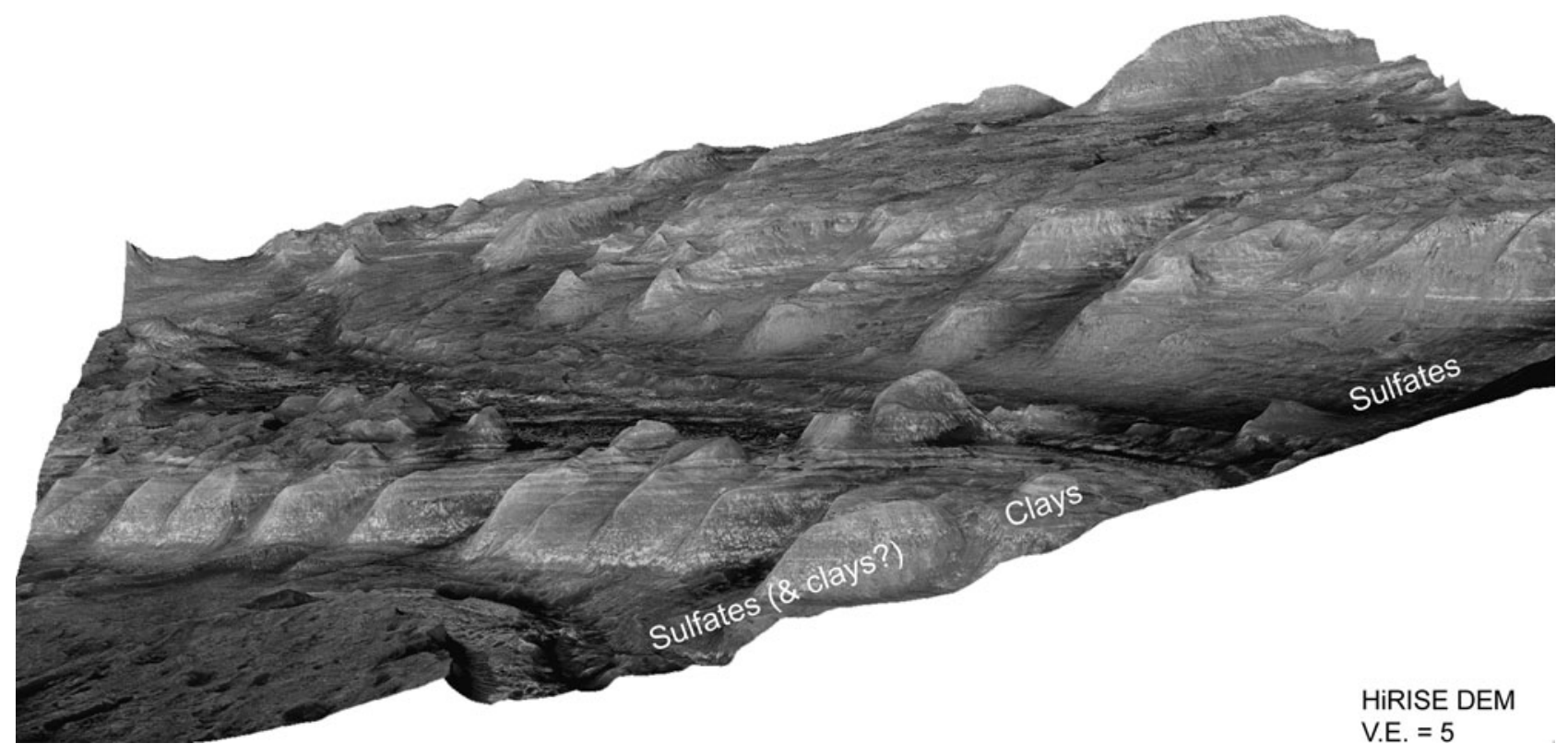

FIG. 2. Perspective view to Lower Gale Mound deposits (Milliken et al., 2010) showing stratigraphic change from clay-rich strata to overlying sulfate-rich strata. Beds dip gently to the northwest at $2-4^{\circ}$ and vary vertically in thickness, albedo, and texture. The mineralogy of beds also correlates with changes in stacking patterns such that clay-rich strata tend to be thin bedded, whereas sulfate-rich units show thicker, possibly amalgamated, bedding. This image shows exposures through a section about $300 \mathrm{~m}$ high; the complete stratigraphic section at Gale exceeds $5000 \mathrm{~m}$.

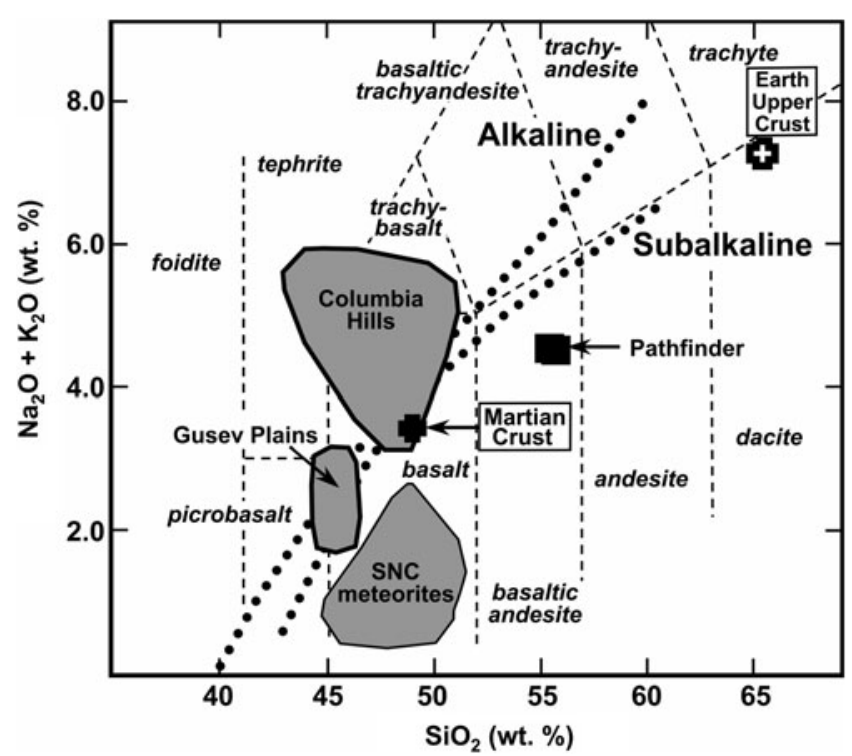

FIG. 3. Plot of $\left(\mathrm{Na}_{2} \mathrm{O}+\mathrm{K}_{2} \mathrm{O}\right)$ versus $\mathrm{SiO}_{2}$ for known igneous rocks from Mars, including fields for martian meteorites and in situ analyses from various landing sites. Also shown are estimates of the bulk composition of the martian upper crust and terrestrial upper continental crust (Taylor and McLennan, 2009). The martian crust is basaltic in character and has a chemical and mineralogical character that fundamentally differs from the terrestrial "granodioritic" upper crust. This difference in turn will have profound implications for the chemical and mineralogical composition of martian sedimentary rocks and how processes, such as weathering, sorting, and diagenesis, will influence these compositions.

\section{What Were/Are the Mechanisms for Sediment Production on Mars, and Did These Processes or Rates Vary through Geological Time?}

As on Earth, sediment production on Mars occurs through physical and chemical weathering. The presence of sedimentary strata, eolian bedforms, fluvial networks, glacial ice caps, and blankets of impact ejecta show that significant volumes of sediment have been generated on Mars. The fundamental question is, by what mechanisms were these sediments generated? Orbital and surface images show clear evidence for physical weathering driven by eolian abrasion, thermal stress, permafrost processes, gravity-driven mass wasting, and salt weathering (Bell et al., 2004; Squyres et al., 2004). Eolian processes may have been a very significant contributor to erosion through saltation-induced impact abrasion.

In the past, fluvial incision of bedrock would have likely been driven by saltation abrasion and rock plucking. The overall nature of chemical weathering departs significantly from Earth's carbon cycle, instead occurring within a sulfur cycle dominated by low $\mathrm{pH}$, water limitation, and cold environments (Hurowitz and McLennan, 2007; McLennan and Grotzinger, 2008), where chemical reactions are incomplete (Madden et al., 2004; Tosca and Knoll, 2009) and terminated by freezing and evaporation (Zolotov and Mironenko, 2007). Another fundamental point of departure is that there is fairly broad consensus that plate tectonics do not, and have not, operated on Mars.

Finally, there is one very important process for sediment generation on Mars that has been well appreciated on the Moon: impact shattering of bedrock (Haskin et al., 2003; Petro and Pieters, 2008). This also was likely a very important process on Mars, particularly early on in its history 
when impact flux was highest, before the end of late heavy bombardment. The early stratigraphic record of Mars preserved at Mawrth Vallis shows clear evidence for impacts preserved as backfilled topographic depressions (Fig. 4). However, in contrast to the Moon, the presence of a significant atmosphere and high $g$ ( $\sim 0.4$ Earth) led to lateral transport of sediments by wind, water, and gravity. This may have created a rock record consisting of impactderived debris, which was reworked by surface processes to form significant sedimentary deposits ultimately formed of impact-generated sediments (Sumner, unpublished data).

Spot estimates of denudation rates for the more recent (non-aqueous) history of Mars range from comparable to the slowest rates observed on Earth to orders of magnitude slower (Golombek and Bridges, 2000; Golombek et al., 2006). Does our current understanding of weathering on Mars account for the observed volume of sediment on the planet? What is the relative balance between physical and chemical weathering in sediment production? How have the nature and rate of sediment production varied over time with planetary evolution and, spatially, by latitude, elevation, and environment?

\section{How Did Source-to-Sink Sediment Transport Systems Evolve on Mars?}

Source-to-sink sediment transport, which links erosional and depositional landscapes in space and time, will provide a unifying concept for evaluating the surface evolution of Mars, just as it does on Earth (see Allen, 2008). Noachian-age terrain on Mars shows long-range fluvial valley networks, exhumed meandering and other channels, deltaic sediment bodies formed in (paleo?) crater lakes, and channel-linked crater-lake chains (Fassett and Head, 2008; Pondrelli et al., 2008). Do these features record long-lived wetter and warmer Noachian conditions or transient conditions associated with impact bombardment-related increases in temperature and water abundance (e.g., Howard et al., 2005)? Did meteoric precipitation result from global hydrologic cycling or humidity created as a result of local processes, such as impact-generated groundwater expulsion? Did long-range transport systems develop as classic headward-eroding systems, or did they evolve progressively downstream through lake spillovers from closed crater basins (Grant and Parker, 2002)?

The end of Noachian time records a dramatic change in martian fluvial systems; huge equatorial outflow channels from pressurized groundwater sources episodically debouched into the northern lowlands (Warner et al., 2009), perhaps forming transient seas. The "chaos" regions (enormous breccias) from which these outflows would have emerged locally contain layered sedimentary strata that host sulfate minerals. Some of these strata have been interpreted as deep-lake environments that contain sublacustrine fan deposits (Metz et al., 2009). These environments represent terminal sediment sinks (e.g., Fig. 5). Since the Amazonian, and perhaps throughout martian history, eolian transport has been the dominant sedimentary process on Mars. However, many surface dunes seem indurated, and the ripple field examined at Meridiani Planum has been inactive for $\sim 100 \mathrm{ka}$ (Golombek et al., 2010). What is the frequency

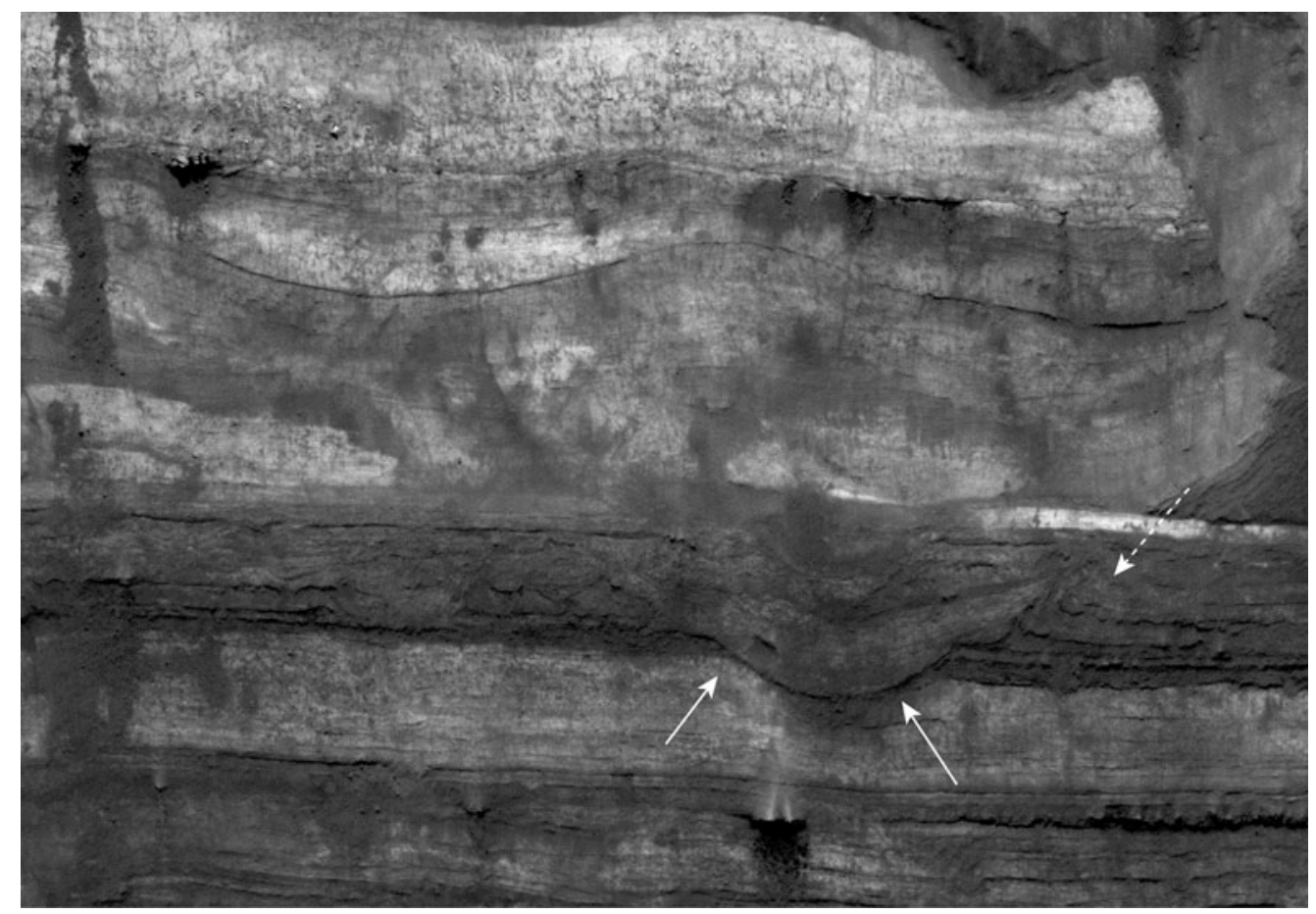

FIG. 4. Strata on wall of small crater, Mawrth Vallis region. This stratigraphic succession exposes a buried impact crater in cross section. Note dark stratigraphic unit pierced by impact depression, marked by solid arrows. This depression is backfilled by younger strata that onlap paleocrater to right. Also note overturned strata (dashed arrow) along right margin of buried impact. Bounding strata may represent reworking of impact-derived detritus. 
FIG. 5. Sublacustrine fan systems in Southern Melas Basin, Valles Marineris (Metz et al., 2009).

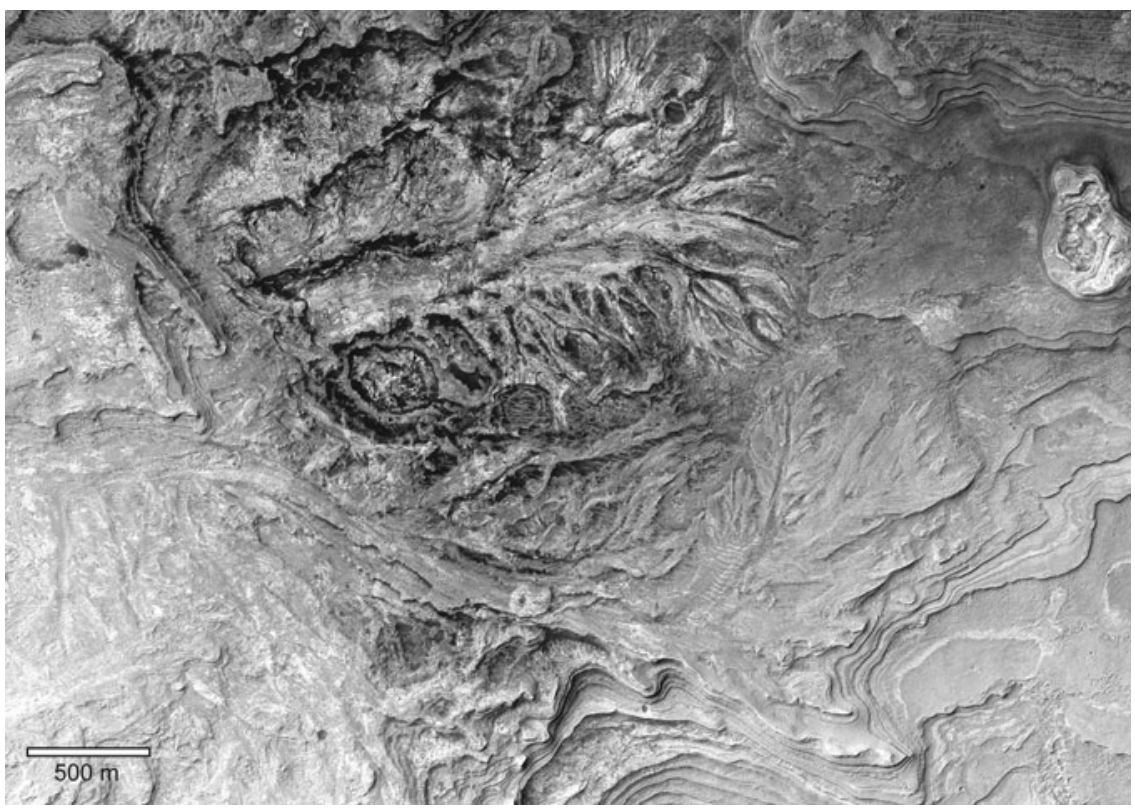

and nature of wind transport on Mars? Does sand transport on Mars occur as "events" marked by low frequency and high energy? Are the sand-transporting winds part of the global circulation (Anderson et al., 1999), or are they derived from localized katabatic winds, episodic storms, or cyclic stimulus ranging from seasonal to Milankovitch? Is there long-distance transport of sand, or are most dune fields locally derived?

Finally, there appear to be vast deposits of wind-blown dust, analogous perhaps to loess deposits but accumulated on a spatial and temporal scale unlike anything that ever occurred on Earth (see Fig. 6; Lewis et al., 2008; Bridges et al., 2010). In the absence of rainfall over hundreds of millionsperhaps a billion or more years-what would the dust cycle look like, and why are these deposits in a net state of erosion today?

\section{What Were the Mechanisms of Sediment Accumulation and Sediment Preservation?}

Sedimentary deposits have been identified across the southern hemisphere and near the equator of Mars, at distinct scales of observation from orbiters and landers. A variety of eolian facies tracts (Grotzinger et al., 2005), alluvial geomorphological elements (Pondrelli et al., 2008), and sublacustrine sediment fan deposits (Metz et al., 2009) have been documented. There are many occurrences of "layered deposits" (e.g., Fig. 6); and, because we see abundant examples

FIG. 6. Strata in the uppermost portion of a $\sim 5 \mathrm{~km}$ tall mound of sedimentary rocks in Gale Crater. Unlike strata exposed lower in the succession (Fig. 2), these outcrops lack spectral signatures indicative of aqueous alteration minerals. Coupled with their regular thickness and albedo, this suggests these strata may represent lithified eolian dust deposits whose deposition and erosion are modulated by external (orbital) forcing (e.g., Lewis et al., 2008; Milliken et al., 2010). Image is a subset of HiRISE image PSP 009927_1750.

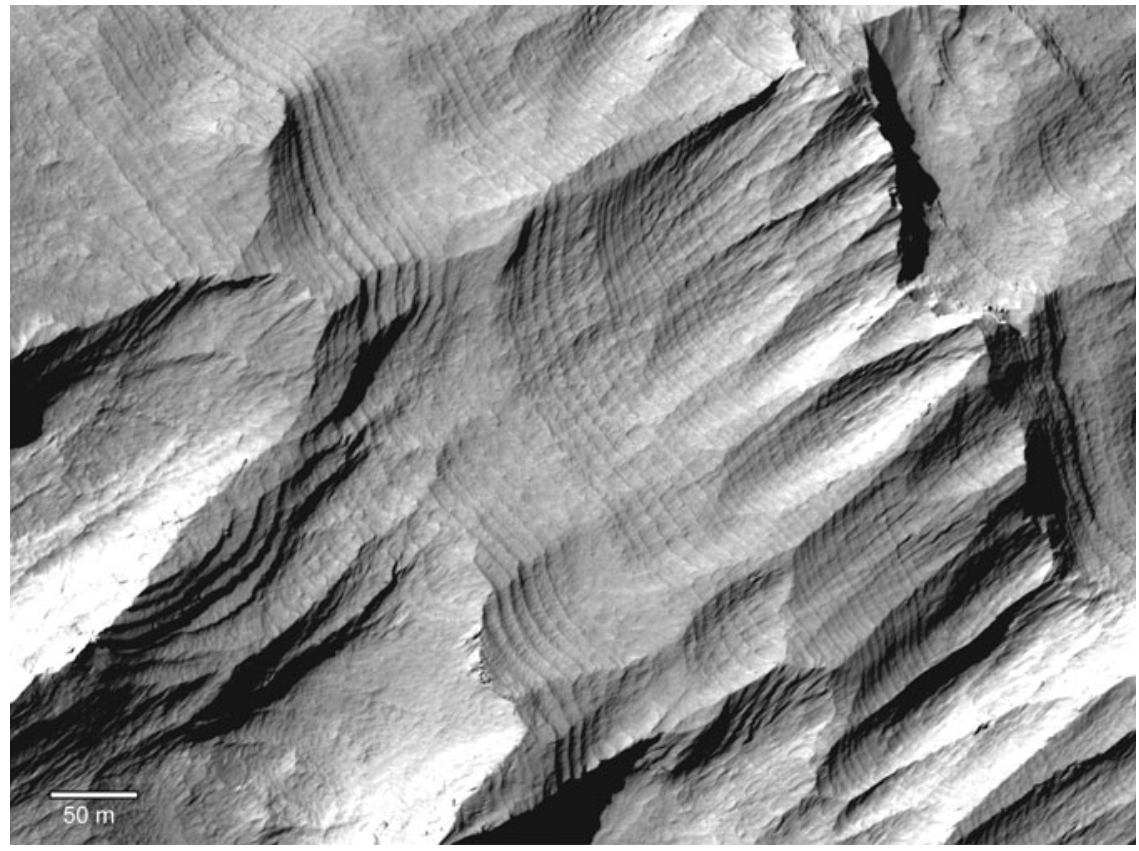


of eroded sedimentary rocks, it is suspected that the sedimentary record was previously much more continuous than it is today at the surface of Mars.

On Mars, lithospheric geodynamics (i.e., subsidence) is not the primary mechanism for creating accommodation space for sediment to fill. Putting aside the northern plains of Mars, the origin of which is controversial (e.g., Marinova et al., 2008), the Valles Marineris rift valley system is a spectacular, but unique, case of a massive sediment accumulation (several-kilometer-thick interior layered deposits) that occurred after gravity-related, thin-skin tectonics (Montgomery et al., 2008). Otherwise, large-scale topographic lows evidently resulted from the removal of uppermost crust during impacts that created multi-ring crater basins. Finally, single impact craters represent sites very prone to sediment accumulation and sediment preservation (i.e., core of remnant buttes; Loizeau et al., 2008).

Subsurface ice and liquid water of capillary fringes above underground water tables were certainly essential to the cementation of unconsolidated aerial deposits (i.e., eolian, alluvial sediments). Fluctuations in the level of standing bodies of waters in early Mars topographic enclosures may have organized sedimentary accumulations into distinct depositional units, the recognition of which help in elucidating patterns of base-level change. Typical stratal termination patterns associated with prograding clinothems (i.e., truncations, onlap and downlap features) have been observed (Dromart et al., 2007).

There is a substantial diversity of depositional fans on Mars. Orbital data mostly do not provide the sedimentologic and architectural attributes that would make it possible to easily separate alluvial fans from delta fans and from deepwater, toe-of-slope fans. Similarly, the distinguishing characteristics of lacustrine depositional systems on Mars remain poorly understood and are a major target for possible future exploration. Insights into depositional/diagenetic features from Mars Science Laboratory and other potential future rover missions are expected to contribute significantly to our understanding of martian sedimentary environments. In particular, it is essential to know whether the phyllosilicates and sulfates of the layered deposits are neoformed, authigenic minerals, or reworked particles.

\section{In What Ways Did Martian Sedimentary Rocks Become Modified after Their Deposition?}

It is clear that sedimentary rocks and the alteration minerals (e.g., clay minerals) and chemical precipitates (sulfates, chlorides, sedimentary silica, etc.) within them are a source of data critical to unraveling the climatic and hydrologic history of Mars. What little data exists on the textures of ancient martian sedimentary rocks indicates a strikingly Earth-like range of diagenetic textures (e.g., Fig. 7). However, as terrestrial studies have shown, it can be difficult to reconstruct primary processes given the overprint of diagenetic textures in ancient rocks (e.g., McLennan et al., 2003), and Mars is no exception.

Clay minerals found in martian mudstones or shales, for instance, may be either detrital or authigenic. Whereas the latter may inform us about local fluid chemistry, the former commonly do not and may have been recycled several times. In addition, sulfate-rich sandstone outcrops examined by the Opportunity rover (Fig. 7) have clearly experienced diagenesis (McLennan et al., 2005; Tosca et al., 2005), which raises the question as to how common this process was, or is, on Mars. These processes result in the disruption of primary rock textures and mineral phase changes, particularly for minerals that incorporate redox-sensitive elements or labile structural $\mathrm{H}_{2} \mathrm{O}$, or both (Alpers et al., 2000; Vaniman et al., 2004). Were martian smectites buried deep enough to cause the onset of burial diagenesis and illitization or chloritization (e.g., Awwiller 1993)? Were the porosity and permeability of these ancient sediments such that they were modified by post-depositional interaction with fluids? If so, how extensive were these processes, and have they obscured or erased important textural and mineralogical information? One possible constraint on the thermal and fluid/rock regime of diagenetic environments is the apparent persistence of amorphous silica in ancient sedimentary deposits (Tosca and Knoll, 2009). This suggests
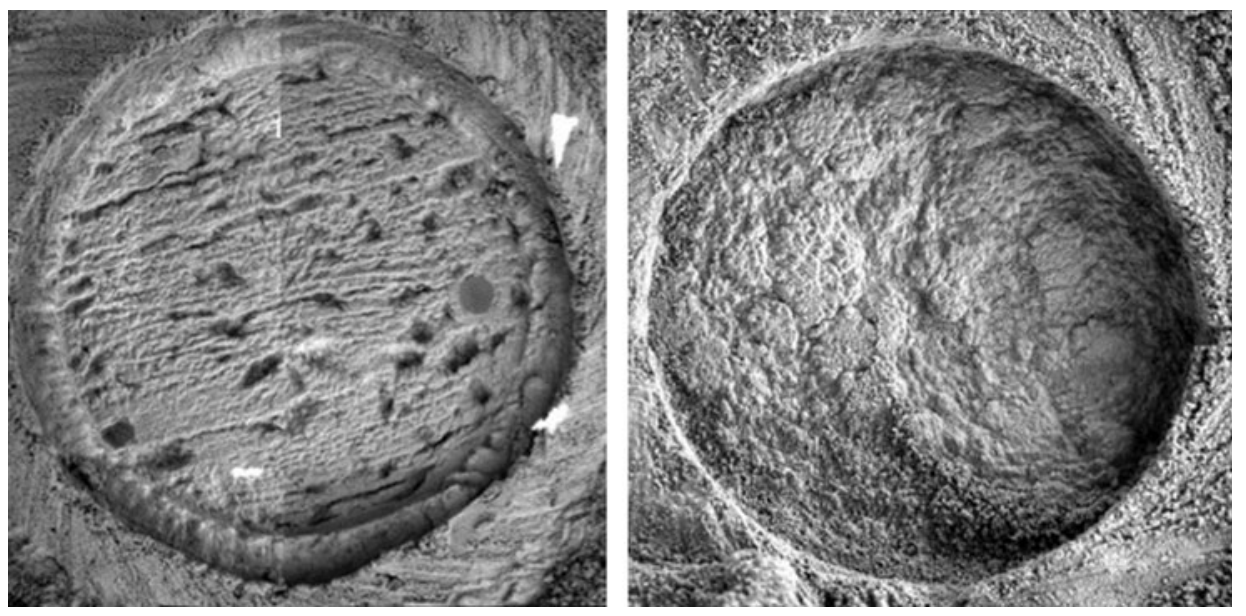

FIG. 7. Diagenetic recrystallization of sulfate-rich sediments on Mars. Left: Well-stratified sulfate-rich sandstone showing crystal molds after unknown (possibly sulfate) mineral and hematitic concretions, some of which are rimmed by later cement. Right: Recrystallization results in homogenization and more coarsely crystalline texture. See McLennan et al. (2005). 
these deposits did not experience sustained interaction with fluids after their initial formation.

Because of their ability to bind and trap organics, the detection of clay minerals on Mars has increased focus in the search for organic material on the Red Planet (e.g., Ehlmann et al., 2008). However, if the composition of these clays (e.g., mixed-layered or illitic) indicates that they have experienced post-depositional heating or interaction with fluids, then their increased maturity may represent a decrease in preservation potential. Therefore, understanding the effects of burial diagenesis and impact processes on martian sediments remains an important area of study. In addition, cementation and lithification processes on Mars remain poorly understood. Although it is difficult to tackle these questions when limited to orbital and rover data, they are nevertheless essential for an accurate interpretation of primary depositional processes and environments of sedimentary rocks on Mars.

\section{Could the Sedimentary Record of Mars Provide Evidence for a Former Biosphere?}

If life ever existed on Mars, it was likely microbial and existed communally in fluids or sediments, either free-living or as biofilms. Biomass from such communities is most likely to have been preserved in the Martian sedimentary rock record (Summons et al., personal communication). With Earth as an analogue (Fig. 8), sedimentary rocks provide a promising setting where organic carbon could be present in sufficient concentration to be detectable via rover-based technologies such as those to be included on Mars Science Laboratory, due to launch in 2011 (Grotzinger, 2009).

A first-pass approach to evaluating the record of potential martian biosignatures would be to seek evidence of sedimentary environments - the preferred geological setting for study_-that may have elevated concentrations of biologically derived carbonaceous materials (Berner, 1982), as well as morphologic textures suggestive of former microbial processes (Cady et al., 2003). These may include quiet water environments, such as lacustrine systems, that promote retention of in situ organics and environments that hydrodynamically concentrate organics. For example, the Eberswalde crater delta appears to have clays concentrated in postulated delta bottomset beds (Milliken and Bish, 2010), and High Resolution Imaging Science Experiment (HiRISE) images suggest prograding foreset strata above the claybearing beds. A second-order consideration would be to seek concentrations of buried crystalline minerals, such as clays and evaporites, which may protect organic matter from the destructive effects of ionizing radiation and strong oxidants (Sumner, 2004). Other promising sedimentary environments would include thermal spring deposits where rapid early mineralization might create both a record of morphologic preservation of former microbial mats as well as preservation of organic compounds (Konhauser et al., 2003). In addition, possible surface-piercing mud diapirs have recently been identified that may have transported subsurface organics, which were potentially deposited in association with regionally widespread deltaic bottomset strata, up to the surface in the Acidalia region of Mars (Oehler and Allen, 2010).

\section{Discussion}

\section{Strategies to answer the key questions}

Each of the seven questions listed above has spawned important research that has led to understanding the sedimentary system on Earth. We have made considerable progress on many of these questions in terrestrial systems, but even on Earth much remains to be done. Of considerable importance is the fact that the methodology to address these questions-particularly with regard to understanding
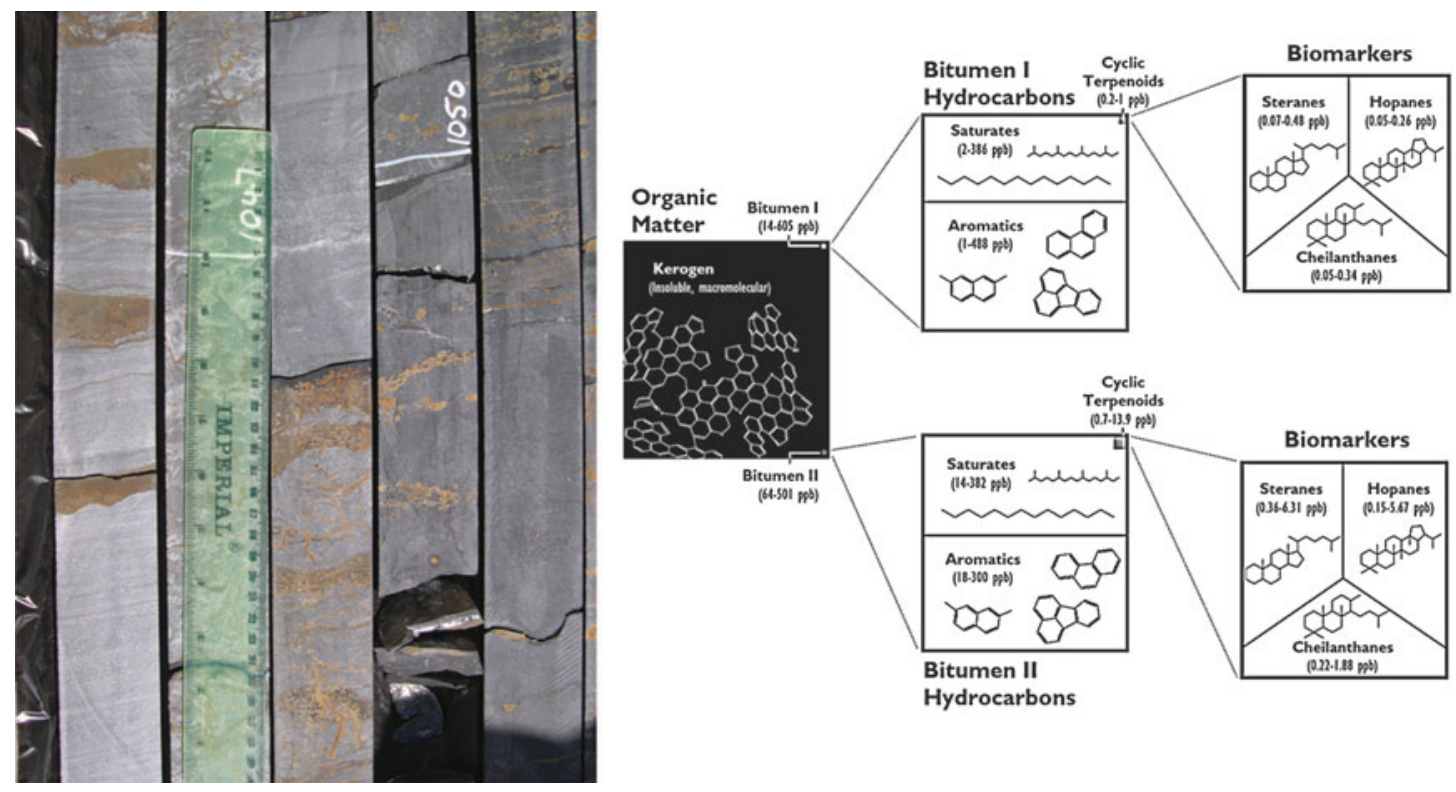

FIG. 8. Left: Organic molecules sequestered in minerals such as on clay surfaces encased in calcite, as shown here in a $2.6 \mathrm{Ga}$ core from South Africa, are protected from oxidation due to low permeability of the host rocks. Right: These organics contain hydrocarbons with very specific distributions of molecular structures that indicate a biological origin as well as provide insights into the ecology of the ancient microbial communities (Waldbauer et al., 2009). 
Earth's earlier history-relies in the first instance on a foundation of field studies of surface exposures, supplemented by comparisons with more recent or modern analogues. This has been appreciated essentially back to the time of Charles Walcott's studies of stromatolites in the Belt Supergroup of Montana (Walcott, 1906). Walcott's appreciation of the possible biogenicity of these structures was stimulated through his observations of modern stromatolites in lakes of upstate New York while working with the New York State Geological Survey, before joining the federal survey and working in Montana.

Experience from the Mars Exploration Rover mission indicates that studying the sedimentary record of Mars can be greatly informed by our experience in studying early Earth. Outcrops of ancient sedimentary rocks are often studied first by using remote sensing data to constrain locations of promising outcrops in relation to major tectonic and lithologic elements. Subsequent work then involves detailed mapping, stratigraphic analysis, and collection of samples for laboratory measurements. All these strategies are available to apply to understanding the martian sedimentary system, including in due course the return of samples to Earth for state-of-the art laboratory analysis.

Accordingly, the following exploration strategies are likely to be effective on Mars.

- In some locations of Mars, such as Vallis Marineris, Sinus Meridiani, and Arabia Terra, it is fairly clear that the vast layered terrains are of sedimentary origin based on stratigraphic, geomorphic, and mineralogical expression. In contrast, there remains considerable uncertainty about the genesis of layered deposits for other parts of Mars. Particularly in the oldest rocks of the southern highlands, it is not yet certain whether layered sequences are sedimentary (and composed of grains derived largely from volcanic rocks), volcanic, or even of deep crustal (metamorphic?) origin (Michalski and Niles, 2010). There are still important unanswered questions involving how different kinds of rocks, of different ages and different places, relate to each other. In addition, we need to differentiate various stratification styles and evaluate the possibility of different environmental histories recorded by suites of minerals and other textural properties in layered terrains. Although the HiRISE camera on Mars Reconnaissance Orbiter has been uniquely valuable in providing initial data to address these kinds of questions, it has covered, as of this writing, only about $1 \%$ of the martian surface in its most useful high-resolution mode. For all these reasons, orbital investigations will continue to be important to answering the key questions posed above.

- Studies of terrestrial geology show that the interpretation of the environmental evolution of terrestrial planets is embedded as a series of proxy records within sedimentary rocks. The best of these records often are preserved in "type" or "reference" sections that form the basis for comparison to possibly similar age strata. It is clear that this would also be very useful on Mars, where vertical profiles may show changes in stratal properties, including, for example, color, albedo, mineralogy, bed thickness, and bed weathering style, to name a few. It might be very helpful to coordinate studies of existing data through the U.S. Geological Survey, which has been responsible for archiving different generations of geological maps. When this was discussed on April 19 at the Mars Sed/Strat conference, a general conclusion was that mineral-based "chemostratigraphy" is clearly the nexus that joins the spectroscopy community with the stratigraphy community.

- Further missions that land and make in situ observations on the surface of Mars are critical. To understand almost all terrestrial (and we presume martian) surficial processes, orbiter-based remote sensing provides only a first pass to ascertain geological context and diversity. Outcrop- and finer-scale studies would be required to establish definitive cross-cutting relationships that unambiguously constrain the timing of sedimentation, primary sedimentary texture and structures, and stratigraphic architecture. Such data would provide constraints on depositional environments and processes. A key goal is developing a quantitative understanding of martian sedimentary processes and the evolution of martian source-to-sink systems. Moreover, data on the alteration/diagenesis of martian sedimentary rocks and the extent to which these rocks have been subjected to burial and metamorphism is necessary.

- Astrobiological studies are also strongly dependent on landed missions to sedimentary terrains. Whether in lacustrine, marine, or thermal spring environments, the scale of observation of sedimentary rocks required to demonstrate biogenicity would require outcrop scale and finer levels of measurement. Features such as stromatolites (and other types of microbially influenced sedimentary structures) can only be recognized in outcrop, and their primary nature must be confirmed by relating morphology and texture to the attributes of underlying and overlying strata. Furthermore, all known concentration mechanisms for organic carbon are fundamentally sedimentary in nature. Future missions that seek to study or sample martian outcrops for evidence of organic carbon would be enhanced by the study of analogous terrestrial sedimentary systems where organic matter is known to be concentrated and preserved. The feedback from these studies for mission planning and surface operations would be to increase both efficiency and the probability of success in discovery.

- In due course, final answers to many of the above questions would necessarily rely on the return of martian samples to Earth, where they could be subjected to the most sophisticated laboratory-based analytical techniques. On Earth, it is typical for field studies to be coupled to follow-on laboratory studies, and the integration of the two kinds of data typically yield extremely powerful interpretations. For example, even simple petrographic analysis of textures and mineralogy can yield great insight into degree of burial, compaction, and lithification history, including the role of water in controlling processes such as cementation. The extraction of detrital and authigenic phases from returned samples that are suitable for age dating could provide quantitative constraints on the history of water interaction, the aqueous alteration of their source terrains, and the age and crustal evolution of these source terrains. 
- Provenance analysis using petrographic, geochemical, and isotopic methods has proven very powerful in evaluating fundamental issues on Earth, such as tectonic setting, source-to-sink basin history, crustal evolution, and paleoclimates (e.g., Dickinson and Suczek, 1979; Hemming et al., 1998; McLennan et al., 2003). Compositional variations observed in martian igneous rocks are substantial (Fig. 2), so bulk mineralogical-geochemical analyses of the type that could be carried out with in situ instruments on board landers and rovers would prove informative. On the other hand, detailed approaches to provenance studies on Mars would differ in detail because the upper crustal sources of the sediment differ on "basaltic Mars" versus "granitic Earth." For example, detrital zircon geochronology, which is central to modern provenance analyses, would be an unavailable tool for martian sediments that might be obtained in a Mars sample return program. On the other hand, single grain analyses of other detrital phases, such as feldspars, phosphates, and volcanic rock fragments, should be available. In addition, on a basaltic planet it could be that baddeleyite replaces zircon as the $\mathrm{ZrO}_{2}$ phase in quartz-unsaturated magmas. This mineral has given precise ages in basaltic terrains on Earth. Accordingly, martian sedimentary sequences are suitable for in situ provenance investigations that use a combination of microtextures, mineralogy, and bulk geochemistry in a similar manner as they are used in the study of shales on Earth. Also, should sedimentary rock samples be returned to Earth, modern "grain by grain" provenance analyses, which have proven to be vital in interpretation of terrestrial settings, could be successfully employed.

\section{Conclusions}

Mars has preserved sedimentary rocks that bear a record of the evolution of its surface environments. The preserved record is highly complementary to the terrestrial stratigraphic record. The oldest martian sedimentary rocks likely exceed 4 billion years; and, on average, the martian record is much older than the terrestrial record. The younger part of the martian stratigraphic record, which likely overlaps with Earth's Archean history, shows a dramatic divergence in the evolution of Mars' surface environments relative to Earth. Perhaps surprisingly, the record on Mars may be better preserved, given the absence of overprinting thermal/metamorphic effects, or penetrative deformation, as is so common in the ancient terrains on Earth that have been affected by plate tectonic processes, including crustal recycling. Accordingly, martian sedimentary geology provides strong potential for the study of a well-preserved record of a dramatically different pathway in the early environmental evolution of a terrestrial planet. It is during this key time interval that life underwent early evolution on Earth. At this time, Mars may have experienced a global change from a wet, $\mathrm{pH}$-neutral planet to a drier, more acidic environment. Martian sediments and sedimentary rocks thus provide the fascinating possibility of studying the divergent evolution of two planetary systems whose surface processes were subject to different initial and boundary conditions, including gravitational constant, crustal differentiation, atmospheric properties, and liquid water composition. Considered in this context, sedimentary geology would achieve its broadest significance.

\section{Acknowledgments}

The work of D. Beaty and J. Hurowitz was carried out for the Jet Propulsion Laboratory, California Institute of Technology, under a contract with the National Aeronautics and Space Administration.

\section{Abbreviation}

HiRISE, High Resolution Imaging Science Experiment.

\section{References}

Allen, P.A. (2008) From landscapes into geological history. Nature 451:274-276.

Alpers, C.N., Jambor, J.L., and Nordstrom, D.K., editors (2000) Sulfate Minerals: Crystallography, Geochemistry, and Environmental Significance, Reviews in Mineralogy and Geochemistry, Vol. 40, edited by P.H. Ribbe, Mineralogical Society of America and The Geochemical Society, Washington DC.

Anderson, F.S., Greeley, R., Xu, P., and Lo, E. (1999) Assessing the martian surface distribution of aeolian sand using a Mars general circulation model. J Geophys Res 104:18991-19002.

Awwiller, D. (1993) Illite/smectite formation and potassium mass transfer during burial diagenesis of mudrocks: a study from the Texas Gulf Coast Paleocene-Eocene. J Sediment Petrol 63:501-512.

Bell, J.F., Squyres, S.W., Arvidson, R.E., Arneson, H.M., Bass, D., Blaney, D., Cabrol, N., Calvin, W., Farmer, J., Farrand, W.H., Goetz, W., Golombek, M., Grant, J.A., Greeley, R., Guinness, E., Hayes, A.G., Hubbard, M.Y.H., Herkenhoff, K.E., Johnson, M.J., Johnson, J.R., Joseph, J., Kinch, K.M., Lemmon, M.T., Li, R., Madsen, M.B., Maki, J.N., Malin, M., McCartney, E., McLennan, S., McSween, H.Y., Ming, D.W., Moersch, J.E., Morris, R.V., Dobrea, E.Z.N., Parker, T.J., Proton, J., Rice, J.W., Seelos, F., Soderblom, J., Soderblom, L.A., Sohl-Dickstein, J.N., Sullivan, R.J., Wolff, M.J., and Wang, A. (2004) Pancam multispectral imaging results from the Spirit rover at Gusev Crater. Science 305:800-806.

Berner, R.A. (1982) Burial of organic carbon and pyrite sulfur in the modern ocean: its geochemical and environmental significance. Am J Sci 282:451-473.

Bibring, J.-P., Langevin, Y., Mustard, J.F., Poulet, F., Arvidson, R., Gendrin, A., Gondet, B., Mangold, N., Pinet, P., Forget, F., and the OMEGA team. (2006) Global mineralogical and aqueous Mars history derived from OMEGA/Mars Express data. Nature 312:400-404.

Bridges, N.T., Banks, M.E., Beyer, R.A., Chuang, F.C., Dobrea, E.Z.N., Herkenhoff, K.E., Keszthelyi, L.P., Fishbaugh, K.E., McEwen, A.S., Michaels, T.I., Thomson, B.J., and Wray, J.J. (2010) Aeolian bedforms, yardangs, and indurated surfaces in the Tharsis Montes as seen by the HiRISE Camera: evidence for dust aggregates. Icarus 205:165-182.

Boynton, W.V., Ming, D.W., Kounaves, S.P., Young, S.M.M., Arvidson, R.E., Hecht, M.H., Hoffman, J., Niles, P.B., Hamara, D.K., Quinn, R.C., Smith, P.H., Sutter, B., Catling, D.C., and Morris, R.V. (2009) Evidence for calcium carbonate at the Mars Phoenix landing site. Science 325:61-64.

Cady, S.L., Farmer, J.D., Grotzinger, J.P., Schopf, J.W., and Steele, A. (2003) Morphological biosignatures and the search for life on Mars. Astrobiology 3:351-368. 
Dickinson, W.R. and Suczek, C.A. (1979) Plate-tectonics and sandstone compositions. Am Assoc Pet Geol Bull 63:21642182.

Dromart, G., Quantin, C., and Broucke, O. (2007) Stratigraphic architectures spotted in southern Melas Chasma, Valles Marineris, Mars. Geology 35:363-366.

Ehlmann, B.L., Mustard, J.F., Fassett, C.I., Schon, S.C., Head, J.W., III, Des Marais, D.J., Grant, J.A., and Murchie, S.L. (2008) Clay minerals in delta deposits and organic preservation potential on Mars. Nat Geosci 1:355-358.

Farquhar, J., Bao, H., and Thiemens, M.H. (2000) Atmospheric influence of Earth's earliest sulfur cycle. Science 289:756-758.

Fassett, C.I. and Head, J.W. (2008) Valley network-fed, openbasin lakes on Mars: distribution and implications for Noachian surface and subsurface hydrology. Icarus 198:37-56.

Golombek, M.P. and Bridges, N.T. (2000) Erosion rates on Mars and implications for climate change: constraints from the Pathfinder landing site. J Geophys Res 105:1841-1853.

Golombek, M.P., Grant, J.A., Crumpler, L.S., Greeley, R., Arvidson, R.E., Bell, J.F., III, Weitz, C.M., Sullivan, R., Christensen, P.R., Soderblom, L.A., and Squyres S.W. (2006) Erosion rates at the Mars Exploration Rover landing sites and long-term climate change on Mars. J Geophys Res 111, doi:10.1029/2006JE002754.

Golombek, M., Robinson, K., McEwen, A., Bridges, N., Ivanov, B., Tornabene, L., and Sullivan, R. (2010) Constraints on ripple migration at Meridiani Planum from Opportunity and HiRISE observations of fresh craters. J Geophys Res 115, doi:10.1029/ 2010JE003628.

Grant, J.A. and Parker, T.J. (2002) Drainage evolution in the Margaritifer Sinus region, Mars. J Geophys Res 107, doi:10.1029/2001JE001678.

Grotzinger, J.P. (2009) Mars exploration, comparative planetary history, and the promise of Mars Science Laboratory. Nat Geosci 2:1-3.

Grotzinger, J.P., Arvidson, R.E., Bell, J.F., III, Calvin, W., Clark, B.C., Fike, D.A., Golombek, M., Greeley, R., Haldemann, A.F.C., Herkenhoff, K.E., Joliff, B.L., Knoll, A.H., Malin, M.C., McLennan, S.M., Parker, T., Soderblom, L.A., Sohl-Dickstein, J.N., Squyres, S.W., Tosca, N.J., and Watters, W.A. (2005) Stratigraphy and sedimentology of a dry to wet eolian depositional system, Burns Formation, Meridiani Planum, Mars. Earth Planet Sci Lett 240:11-72.

Haskin, L.A., Moss, B.E., and McKinnon, W.B. (2003) On estimating contributions of basin ejecta to regolith deposits at lunar sites. Meteorit Planet Sci 38:13-33.

Hecht, M.H., Kounaves, S.P., Quinn, R.C., West, S.J., Young, S.M.M., Ming, D.W., Catling, D.C., Clark, B.C., Boynton, W.V., Hoffman, J., DeFlores, L.P., Gospodinova, K., Kapit, J., and Smith, P.H. (2009) Detection of perchlorate and the soluble chemistry of martian soil at the Phoenix lander site. Science 325:64-67.

Hemming, S.R., Broecker, W.S., Sharp, W.D., Bond, G.C., Gwiazda, R.H., McManus, J.F., Klas, M., and Hajdas, I. (1998) Provenance of Heinrich layers in core V28-82, northeastern Atlantic: Ar-40/Ar-39 ages of ice-rafted hornblende, Pb isotopes in feldspar grains, and $\mathrm{Nd}-\mathrm{Sr}-\mathrm{Pb}$ isotopes in the fine sediment fraction. Earth Planet Sci Lett 164:317-333.

Holland, H.D. and Rye, R. (1997) Evidence in pre-2.2 Ga paleosols for the early evolution of atmospheric oxygen and terrestrial biota: discussion and reply. Geology 25:857-859.

Howard, A.D., Moore, J.M., and Irwin, R.P. (2005) An intense terminal epoch of widespread fluvial activity on early Mars: 1. Valley network incision and associated deposits. J Geophys Res 110, doi:10.1029/2005JE002459.
Hurowitz, J.A. and McLennan, S.M. (2007) A 3.5 Ga record of water-limited, acidic conditions on Mars. Earth Planet Sci Lett 260:432-443.

Konhauser, K.O., Jones, B., Reysenbauch, A.-L., and Renaut, R.W. (2003) Hot spring sinters: keys to understanding Earth's earliest life forms. Can J Earth Sci 40:1713-1724.

Lewis, K., Aharonson, O., Grotzinger, J.P., Kirk, R.L., McKewan, A.S., and Suer, T.-A. (2008) Quasi-periodic bedding in the sedimentary rock record of Mars. Science 322:1532-1535.

Loizeau, D., Mangold, N., Poulet, F., Ansan, V., Hauber, E., Bibring, J.-P., Langevin, B., Gondet, P., Masson, P., and Neukum, G. (2008) Stratigraphy of the Mawrth Vallis region through OMEGA, HRSC color imagery and DTM [abstract 7041]. In Workshop on Martian Phyllosilicates: Recorders of Aqueous Processes, Lunar and Planetary Institute, Houston.

Madden, M.E.E., Bodnar, R.J., and Rimstidt, J.D. (2004) Jarosite as an indicator of water-limited chemical weathering on Mars. Nature 431:821-823.

Malin, M.C. and Edgett, K.S. (2000) Sedimentary rocks of early Mars. Science 290:1927-1937.

Marinova, M.M., Aharonson, O., and Asphaug, E. (2008) Megaimpact formation of the Mars hemispheric dichotomy. Nature 453:1216-1219.

McLennan, S.M. and Grotzinger, J.P. (2008) The sedimentary rock cycle of Mars. In The Martian Surface: Composition, Mineralogy, and Physical Properties, edited by J.F. Bell III, Cambridge University Press, Cambridge, pp 541-577.

McLennan, S.M., Bock, B., Hemming, S.R., Hurowitz, J.A., Lev, S.M., and McDaniel, D.K. (2003) The roles of provenance and sedimentary processes in the geochemistry of sedimentary rocks. In Geochemistry of Sediments and Sedimentary Rocks: Evolutionary Considerations to Mineral Deposit-Forming Environments, edited by D.R. Lentz, GEOtext 4, Geological Association of Canada, St. John's, Canada, pp 7-38.

McLennan, S.M., Bell, J.F., III, Calvin, W.M., Christensen, P.R., Clark, B.C., De Souza, P.A., Jr., Farmer, J., Farrand, W.H., Fike, D.A., Gellert, R., Ghosh, A., Glotch, T.D., Grotzinger, J.P., Hahn, B.C., Herkenhoff, K.E., Hurowitz, J.A., Johnson, J.R., Johnson, S.S., Joliff, B.L., Klingelhoefer, G., Knoll, A.H., Learner, Z.A., Malin, M.C., McSween, H.Y., Jr., Pocock, J., Ruff, S.W., Soderblom, L.A., Squyres, S.W., Tosca, N.J., Watters, W.A., Wyatt, M.B., and Yen, A. (2005) Provenance and diagenesis of the evaporite-bearing Burns Formation, Meridiani Planum, Mars. Earth Planet Sci Lett 240:95-121.

McSween, H.Y., Jr., Taylor, G.J., and Wyatt, M.B. (2009) Elemental composition of the martian crust. Science 324:736739.

Metz, J.M., Grotzinger, J.P., Mohrig, D., Milliken, R., Prather, B., Pirmez, C., McEwen, A.S., and Weitz, C.M. (2009) Sublacustrine depositional fans in southwest Melas Chasma. J Geophys Res 114, doi:10.1029/2009JE003365.

Michalski, J.P. and Niles, P.B. (2010) Deep crustal carbonate rocks exposed by meteor impact on Mars. Nat Geosci 3:751755.

Milliken, R.E. and Bish, D. (2010) Sources and sinks of clay minerals on Mars. Philosophical Magazine 90:2293-2308.

Milliken, R.E., Fischer, W.W., and Hurowitz, J.A. (2009) Missing salts on early Mars. Geophys Res Lett 36, doi:10.1029/2009 GL038588.

Milliken, R.E., Grotzinger, J.P., and Thomson, B.J. (2010) Paleoclimate of Mars as captured by the stratigraphic record in Gale Crater. Geophys Res Lett 37, doi:10.1029/2009GL041870.

Montgomery, D.R., Som, S.M., Jackson, M.P.A., Schreiber, B.C., Gillespie, A.R., and Adams, J.B. (2008) Continental-scale salt 
tectonics on Mars and the origin of Valles Marineris and associated outflow channels. Geol Soc Am Bull 121:117-133.

Morris, R.V., Ruff, S.W., Gellert, R., Ming, D.W., Arvidson, R.E., Clark, B.C., Golden, D.C., Siebach, K., Klingelhofer, G., Schroder, C., Fleischer, I., Yen, A.S., and Squyres, S.W. (2010) Identification of carbonate-rich outcrops on Mars by the Spirit rover. Science 329:421-424.

Murchie, S.L., Mustard, J.F., Ehlmann, B.L., Milliken, R.E., Bishop, J.L., McKeown, N.K., Noe Dobrea, E.Z., Seelos, F.P., Buczkowski, D.L., Wiseman, S.M., Arvidson, R.E., Wray, J.J., Swayze, G., Clark, R.N., Des Marais, D.J., McEwen, A.S., and Bibring, J.-P. (2009) A synthesis of martian aqueous mineralogy after 1 Mars year of observations from the Mars Reconnaissance Orbiter. J Geophys Res 114, doi:10.1029/2009 JE003342.

Oehler, D.Z. and Allen, C.C. (2010) Evidence for pervasive mud volcanism in Acidalia Planitia, Mars. Icarus 208:636-657.

Petro, N.E. and Pieters, C.M. (2008) The lunar-wide effects of basin ejecta distribution on the early megaregolith. Meteorit Planet Sci 43:1517-1529.

Pondrelli, M., Rossi, A.P., Marinangeli, L., Hauber, E., Gwinner, K., Baliva, A., and Di Lorenzo, S. (2008) Evolution and depositional environments of the Eberswalde fan delta, Mars. Icarus 197:429-451.

Rasmussen, B. and Buick, R. (1999) Redox state of the Archean atmosphere: evidence from detrital heavy minerals in $c a$. 3250-2750 Ma sandstones from the Pilbara Craton, Australia. Geology 27:115-118.

Squyres, S.W., Grotzinger, J.P., Arvidson, R.E., Bell, J.F., III, Calvin, W., Christensen, P.R., Clark, B.C., Crisp, J.A., Farrand, W.H., Herkenhoff, K.E., Johnson, J.R., Klingelhofer, G., Knoll, A.H., McLennan, S.M., McSween, H.Y., Jr., Morris, R.V., Rice, J.W., Jr., Rieder, R., and Soderblom, L.A. (2004) In situ evidence for an ancient aqueous environment at Meridiani Planum, Mars. Science 306:1709-1714.

Summons, R.E., Amend, J.P., Bish, D., Buick, R., Cody, G.D., Des Marais, D.J., Dromart, G., Eigenbrode, J.L., Knoll, A.H., and Sumner, D.Y. (2011) Preservation of martian organic and environmental records: Final Report of the Mars Biosignature Working Group. Astrobiology (in press).

Sumner, D.Y. (2004) Poor preservational potential of organics in Meridiani Planum hematite-bearing sedimentary rocks. J Geophys Res 109, doi:10.1029/2004JE002321.

Taylor, S.R. and McLennan, S.M. (1985) The Continental Crust: Its Composition and Evolution, Blackwell Scientific Publications, Oxford.
Taylor, S.R. and McLennan, S.M. (2009) Planetary Crusts: Their Composition, Origin and Evolution, Cambridge University Press, Cambridge.

Taylor, G.J., McLennan, S.M., McSween, H.Y., Jr., Wyatt, M.B., and Lentz, R.C.F. (2008) Implications of observed primary lithologies. In The Martian Surface: Composition, Mineralogy, and Physical Properties, edited by J.F. Bell III, Cambridge University Press, Cambridge, pp 501-518.

Tosca, N.J. and Knoll, A.H. (2009) Juvenile chemical sediments and the long term persistence of water at the surface of Mars. Earth Planet Sci Lett 286:379-386.

Tosca, N.J., McLennan, S.M., Clark, B.C., Grotzinger, J.P., Hurowitz, J.A., Knoll, A.H., Schroder, C., and Squyres, S.W. (2005) Geochemical modeling of evaporation processes on Mars: insight from the sedimentary record at Meridiani Planum. Earth Planet Sci Lett 240:122-148.

Vaniman, D.T., Bish, D.L., Chipera, S.J., Fialips, C.I., Carey, J.W., and Feldman, W.C. (2004) Magnesium sulphate salts and the history of water on Mars. Nature 431:663-665.

Walcott, C.D. (1906) Algonkian formations of northwestern Montana. Bulletin of the Geological Society of America 17:1-23.

Waldbauer, J.R., Sherman, L.S., Sumner, D.Y., and Summons, R.E. (2009) Late Archean molecular fossils from the Transvaal Supergroup record the antiquity of microbial diversity of aerobiosis. Precambrian Res 169:28-47.

Warner, N., Gupta, S., Muller, J.P., Kim, J.-R., and Lin, S.-Y. (2009) A refined chronology of catastrophic outflow events in Ares Vallis, Mars. Earth Planet Sci Lett 288:58-69.

Wray, J.J., Squyres, S.W., Roach, L.H., Bishop, J.L., Mustard, J.F., and Dobrea, E.Z.N. (2010) Identification of the Ca-sulfate bassanite in Mawrth Vallis, Mars. Icarus 209:416-421.

Zolotov, M.Y. and Mironenko, M.V. (2007) Timing of acid weathering on Mars: a kinetic-thermodynamic assessment. J Geophys Res 112, doi:10.1029/2006JE0025882.

Address correspondence to: John Grotzinger Division of Geological and Planetary Sciences California Institute of Technology Pasadena, CA 91106 USA

E-mail: grotz@gps.caltech.edu

Submitted 10 November 2010 Accepted 11 November 2010 